\title{
FAT TAXES AND PROMOTIONAL TAX DIMENSION
}

\begin{abstract}
Nutritional taxation includes the collection of tax instruments, relating to assumption the consumption, sale or production of food injurious to health human, whose preservation in the food sector is ensured by multiple models: administrative coercive measures, aimed to limiting the harmful food consumption; fat taxes, with which subject to taxation "junk foods", discouraging the use, in order to increase the consumption of foods less harmful and adopting healthier lifestyles; food regulations, aimed to inducing the producers to place on the market products sanitary; communication campaigns, information, awareness and education. In short, fat taxes are the result of the evolution of the tax order, that, to acquisitive and redistributive logic, own of matter, supports a promotional logic, susceptible to direct taxpayer food choices.
\end{abstract}

KEYWORDS: protection of human health; paternalism; junk food; promotional taxation; fat taxes

\section{THE PROTECTION'S TOOLS OF HUMAN HEALTH IN THE FOOD SECTOR: THE NUTRITIONAL TAXATION}

The protection of human health - in the food sector - is ensured by multiple tools able to affect the lifestyle of the individual: on the one hand, measures administrative-coercive, conveyed by policies of "command and control", aimed to limiting the harmful food consumption, by means of textual legislative bans, and to sanction conducted or eating habits nonvirtuous; secondly, institutes of tax nature (so-called "fat taxes") (Uricchio, 
2013, p. 1268 ff.; Drenkard, 2013, p. 195 ff.; Quaglino, 2013, p. 239 ff.), which subject to tax higher "junk foods", harmful to human health, discouraging the use, in order to stimulate the consumption of less harmful and encourage healthier lifestyles.

On the point, there is no lack of food regulations, making use of the principles of civil liability, direct to induce producers to place on the healthy products market; so like, are not irrelevant prevention interventions, softer but stronger in the long run, entrusted to communication campaigns, information, awareness and education feed (Uricchio, 2015, p. 290; Magli, 2014, p. 1316).

The use of taxation to guide food choices have recently taken importance in public policy, helping to spread in the ideology of legislators and in the vocabulary of citizens the locutions "fat tax", "soda tax" and "junk food tax" (Trovato, 2013, p. 7).

In this light, the hendiadys "nutritional taxation" refers to the collection of tax tools, related in large part to the field of indirect taxation, which have as a prerequisite the consumption, sale or production of foods harmful to health: the attempt is to remedy the problem of overfeeding, understood as malnutrition for excess, contributing to reduce risk factors at the base of certain diseases.

The configuration denotes the affinity between the fat taxes and excise duties (on the matter, comp. Pace, 1994, p. 267 ff.; Cerrato, 1996, p. 215 ff.; Fichera, 1997, p. 216 ff.; Schiavolin, 2000, p. 22 ff.; Cipolla, 2003, p. 1859 ff.; Verrigni, 2003, p. 487 ff.; Boria, 2004, p. 504 ff.; Cipolla, 2006, p. 72 ff.; Verrigni, 2007, p. 251 ff.; Boria, 2008, p. 811 ff.; Tesauro, 2008, p. 344 ff.; Tullock, 2013, p. 97 ff.; Williams - Christ, 2013, p. 187 ff.; Falsitta, 2014, p. 631 ff.), imposed on the manufacture and sale of consumer products, originally applied right to the consumption of food nature: example, in this regard, it is the English experience, which, as early as 1643, predicted the excise duties on beer, on brandy, on cider and on other drinks, then resumed in other European legal systems (Uricchio, 2015, p. 298, nt. 71).

In this light, the taxes on unhealthy foods would add to harmonised excise duties - covered by Directive 2008/118/EU, implemented in Italy with the d.lgs. 29 march 2010, n. 48 -, without giving rise to the phenomena of double imposition, because of different tax assumption: excise taxes affect the 
amount of goods produced, with rates linked to the measurement's unit of the product; the fat taxes, however, are applied in relation to the effects on human health, taking into account the amount and weight of saturated fat content in food (Uricchio, 2015, p. 298).

The problem of malnutrition - as imbalance between nutrients, namely between the energy that a body receives and the actual daily requirements of the body - takes on two different configurations: malnutrition for defect, also called undernutrition, typical of third world countries; malnutrition for excess (Labate, 2012, p. 20 ff.; Tiffin - Salois, 2013, p. 143 ff.), also called overfeeding, widespread in advanced societies of the world western.

In both assumptions, effects for human health appear deleterious: next to malnutrition, overeating causes serious non-communicable diseases - such as cardiovascular diseases, diabetes and cancer - susceptible to determine lethal consequences and undermine the well-being of the whole nation in reason of the direct costs (medical treatment) and indirect costs (reduction of the quality of life; loss of earning capacity).

The World Health Organization (WHO) (Oms, 2004; Oms, 2008), on a number of occasions, stressed that, after the pollution and smoking, factors higher risk, with a considerable impact on mortality and on morbidity, are those related to a sedentary lifestyle and overweight, caused by incorrect nutritional styles, linked to eating habits that favor diets based on fatty foods, sodas and genetically modified products (GMOs) (on the matter, comp. Marini, 2004, p. 7 ff.; Marini, 2007, p. 1 ff.; Di Benedetto, 2011; Tafaro, 2014, p. 253 ff.; Cavanna, 2014, p. 464 ff.; Cavanna, 2014, p. 548 ff.): excessive intake of sugar and fat, raising the risk of obesity, is a source of negative metabolic effects, strokes, heart disease, stroke, capable of generating cancer, diabetes and other serious illnesses (Uricchio, 2015, p. 289).

In same terms, the "Political declaration on the prevention and control of non-communicable diseases ", adopted by the General Assembly of the the United Nations on 19 September 2011, points out that not virtuous lifestyles - based on the consumption of tobacco and alcohol - together little healthy diets and lack of physical activity, in addition to negatively affect on human health, cause worrisome consequences of social and economic nature (Alemanno - Carreño, 2013, p. 235). 


\section{THE FAT TAXES: LEGAL NATURE; FOUNDATION; EFFECTS. STATE INTERVENTION IN THE CHOICES OF INDIVIDUALS: THE PATERNALISM}

The fat taxes represent, therefore, the result of the evolution of the tax legal system, which, to the original acquisitive and redistributive logic, supports promotional logic, for guide the choices of the taxpayers of favoring a balanced diet, accompanied by healthy lifestyles.

They are, to a large part, selective tax (on the matter, comp. Holcombe, 2013, p. $61 \mathrm{ff}$.), applied to the production or consumption of unhealthy foods, in order to protect the health of citizens, potential source of externalities and public goods, especially in the presence of public healthcare systems. Indeed, since affect on goods from inelastic demand, food tax can guarantee, as a side effect, an additional income to the treasury (Trovato, 2013, p. 11).

These fiscal measures, given care also by the World Health Health (Thow - Jan - Leeder - Swinburn, 2010, p. 609 ff.), on assumption that the junk food is the most economical on the market, enhance the idea of using tax tool to align the selling prices of such food to those currents, allocating the difference of revenue to fund nutrition education campaigns (Uricchio, 2015, p. 292). The idea was developed by the North American doctrine (Brownell, 15 December 1997, 2; Brownell - Battle Horgen, 2004) on the model of pigouvian's tax (on the matter, comp. Pigou, 1948), including in the market price of certain goods the external diseconomies generated by consumption.

In other words, because the selling price of junk food does not reflect the social cost borne by community, using taxation to raise the final consideration in order to discourage consumption (Uricchio, 2015, p. 292).

Therefore, if the tax affects the production, as a result of a mechanism for tax translation (on the matter, comp. Allena, 2005), tend to be burdening the whole weight on the final consumer, rather than about the manufacturer, to avoid that, by shifting the tax burden on the latter, the taxpayer's preferences remain constant (Uricchio, 2015, p. 292).

In economic science, State intervention with regard to the citizens's choices is called "paternalism" (Uricchio, 2015, p. 293; on the matter, comp. Dworkin, 2002; Nucciarelli, 2012; Shughart II, 2013, p. 35 ff.; Glaeser, 2013, p. $107 \mathrm{ff}$.). The term - which generic propensity of public sector to govern 
the conduct of the individual to promote better choices than the same would operate independently, or to promote virtuous behavior, faces to preserve the integrity and human health or inhibit harmful conduct - can be taken in two different forms: the "strong paternalism", in in cases where the conduct of the individual is forbidden or conditioned by the authority; the "weak or libertarian paternalism" in cases of choice addressed to the prediction of incentives/disincentives or of information otherwise neglected by the consumer (for example, the designation of caloric intake of individual components of the product), without there being an obligation or prohibition (Trovato, 2013, p. 9).

In this light, promoting virtuous behaviour allows to spread a new culture, founded on dialogue between the citizen and the State authority.

Emerges, therefore, that the item discretive between the different forms of paternalism doesn't concerns the formal aspect, which involve the external structure the intervention of the State, but the impact of the intervention on the choice of individual (Trovato, 2013, p. 10).

Despite the lack of uniformity of opinion (Trovato, 2013, p. 9), fat taxes are among the forms of "weak paternalism," posed in defense of public health, whose lesion may generate negative externalities, resulting in costs borne by the community (Uricchio, 2015, p. 293).

In the past, the technique of food taxation was used to reasons of mere tax revenue, namely in order to achieve revenue, without a incentive logic, being no stranger to the enforcement mechanism of the tribute the appreciation of any deleterious effects on human health (Uricchio, 2015, p. 281).

In this light, the liability to taxation of foodstuffs, rather than appear new, emerged with the primary objective of tax policies, because they are a source of easy and safe revenue, albeit obnoxious: not surprisingly, the taxes on salt, grain and tea have formed, in the past, the motive of wars and riots (Trovato, 2013, p. 7; on the influence covered by the taxation on the history of humanity, often source of revolutionary movements, comp. Adams, 2007). It consisted largely of tributes which assumed processing, production and consumption of mainstream food products, such as, for example, the "charge on the ground" (Carano Donvito, 1928, p. 286; Uricchio, 2017, p. 20) - introduced immediately after the unification of Italy, with law 7 july 1868 , 
n. 4490 , to ensure a balanced budget - or the tax on the ice, on the chicory, on the sugar or other surrogates of coffee, falling at that time among the assets of luxury (Uricchio, 2015, p. 282-283).

Only recently, the need to promote correct eating habits prompted the legislator to support direct adjustment models, having nature penalties and authorization and considered inappropriate over time, certain instruments of tax nature, likely to guide the nutritional habits and to influence taxpayers behaviour through the liability to taxation of harmful foods and the tax abatement of healthy foods: for example, foods falling the Mediterranean diet. In other words, they are economic measures (so-called "marked based instruments") and facilitating corrective or incentive levies that increase the sale price of junk food (foods fats and sodas), restricting the purchase and engraving on the equilibrium of the market (Uricchio, 2015, p. 283-290).

\section{VERIFICATION OF COMPATIBILITY OF FAT TAXES WITH THE PRINCIPLE OF ABILITY TO PAY. THE CONSTITUTIONALITY OF THE LEVY}

The enhancement of this promotional finality, purely extra taxes (on taxes with finality extra taxes, comp. Fichera, 1973; Fichera, 1973, p. 774 ff.; Aizega Zubillaga, 2001; Balladores Saballos, 2013, p. 29 ff.; Donatelli, 2019, p. 312 ff.), requires to determine the compatibility of fat taxes with the constitutional principles that underlie the tax legal system, first of all the principle of ability to pay (article 53 of Constitution), cannot the extra tax purposes - for these tools real justification of the tribute, prevalent on the purpose of revenue - justify an exception to the this principle, garrison of the constitutionality of levy and expression of corollaries of right allotment and substantial equality (article 3, paragraph 2 of Constitution) (Uricchio, 2015, p. 288).

The question is not of little account: if the assumption of taxation was not such as from manifesting wealth to contribute to public expenditure, these taxes could not find citizenship in the legislative system, in that infringe a basic principle - that of ability to pay - fixed by the Constitutional Charter.

Recognize the correspondence of fat taxes to principle of ability to pay, on the assumption that those tributes affect indirect indices of wealth, such as production and consumption, looks pretty simplistic: famously, the junk 
food has a current price far lower than the less harmful to human health (think of the organic products), generating a false manifestation of wealth.

Therefore, where the index of ability to pay was identified in production or in consumption, junk food should be subject to a levy less burdensome than healthy food, because is at the reach of the taxpayers less affluent, belonging to the lower segments of the population and likely to demonstrate less ability to contribute to public expenditure.

The compatibility with the principle set out in article 53, paragraph 1 , of Constitution is, therefore, to be found elsewhere in "qualified ability to pay", consisting of a saving, even if future and possible, of public spending (rectius, "health care"), especially in jurisdictions, such as Italian, characterized by the presence of a system of public health. Not by chance, the containment of health care costs is an expression of interest to the financial balance, which includes and absorbs the tax interest (Uricchio, 2015, p. 284-285; on the tax interest, comp. Antonini, 1996; Boria, 2002).

Indeed, the ability to pay (on the principle of ability to pay, comp. Griziotti, 1953, p. 351 ff.; Giardina, 1961; d'Amati, 1964, p. 464 ff.; Manzoni, 1967; Micheli, 1967, p. 1530; Gaffuri, 1969; Maffezzoni, 1970; d'Amati, 1973, p. 106 ff.; Moschetti, 1973; Berliri, 1974, p. 114 ff.; La Rosa, 1981, p. 233 ff.; De Mita, 1984; d'Amati, 1985, p. 82 ff.; Marongiu, 1985, p. 6 ff.; De Mita, 1987, p. 454 ff.; Moschetti, 1988, p. 1 ff.; Antonini, 1996, p. 274; Perrone, 1997, p. 577 ff.; Batistoni Ferrara, 1999, p. 345 ff.; Fedele, 1999, p. 971 ff.; Moschetti, 2007, p. 44 ff.; Russo, 2007, p. 48 ff.; Gaffuri, 2008, p. 429 ff.; Parente S.A., 2013, p. 522 ff.; Giovannini, 2013; Giovannini, 2016, p. 15 ff.), in addition to being fundamental, limit and measure of taxation, is a criterion foundation in the allotment of public spending, aimed to protecting taxpayers and to ensure the smooth running of the financial life of the State (Uricchio, 2015, p. 284-285).

The nexus between the levy and expenditure tax, deducible from the letter article 53 of Constitution, has been strengthened by changes in articles 81,97 and 119 of Constitution, made by article 1, Constitutional law 20 April 2012, n. 1, which, to align the home constitutional system within the Community framework of "fiscal compact", elevated to the constitutional principle the so-called "financial stability" (on the matter, comp. Perez, 2012, 
p. 929 ff.; D'Amico, 2012, p. 933 ff.), that is the balance between income and expenditure (Uricchio, 2015, p. 285-286). In addition, the new article 81, paragraph 3, of Constitution has imposed on every law with financial effects, including the "budget bill", to provide directly the means to meet the new and higher expenses, not limited to the mere indication of the resources needed, as was expected in the original formulation of article 81 , paragraph 4 , of Constitution (Uricchio, 2015, p. 285-286).

The term "fiscal compact" (on the matter, comp. Di Pietro, 2012, p. 130 ff.; Napolitano, 2012, p. 461 ff.; Censi, 2017) refers to the "Treaty on stability, coordination and governance in the economic and monetary union" (known as the Pact of European budget), approved, in the EU, on 2 March 2012 by 25 of $28 \mathrm{EU}$ Member States to impose an obligation on the members to maintain healthy and sustainable public finances, while avoiding excessive deficits and safeguarding the economic and financial stability of the whole euro area, through the integration, within the domestic Constitutions, of following principles: a balanced budget; the obligation not to exceed the threshold structural deficit by more than certain parameters $(0.50 \%$ or $1 \%$ for countries whose public debt is less than the $60 \%$ of gross domestic product); the reduction of debt within a certain amount (one twentieth for year, until the report of $60 \%$ of gross domestic product over a twenty year period) (Uricchio, 2015, p. 286).

Therefore, if the principle of ability to pay expresses the connection between protracted economic content - from which is deductible, on the rational level, fitness tax debt - and subjective contributions, these articles 81, 97 and 119 of Constitution denote the commitment to ensure the balance between income and expenses resulting from the budget, using any instrument of financial nature, including tax law (Uricchio, 2015, p. 286-287).

Indeed, in finding this case taxed is rather limited to reference to the classical notion of ability to pay, based on indexes (direct and indirect) detectors of wealth, such as income and assets, consumption, capital gains and acts of exchange: the constitutionality of fat taxes may achieve only considering responding to the principle de quo also fiscal instruments that subject to tax any content likely to generate virtuous effects under the profile of expenditure, in line with community and international commitments 
and with the constitutional principles, first of all those of equality, not to arbitrariness and rationality (Uricchio, 2015, p. 287).

In this light, the assumption of the tax is detected in this case capable of expressing qualified economically assessable vantage points, without identify itself necessarily in direct and indirect indices of wealth (Gallo, 2012, p. 16): where taxpayers, for removal phenomena, waived the consumption or production of harmful foods, the non-tax revenue would be offset by the lower health care costs (Uricchio, 2015, p. 288).

\section{THE DIFFERENT CONFIGURATIONS ASSUMED BY FAT TAXES: THE INCREASE AND STRENGTHENING OF EXISTING TRIBUTES; THE ESTABLISHMENT OF NEW TAXES}

Therefore, the provision of tax measures relating to consumption or production of junk food, resulting in potential savings in public spending - in line with the constitutional principles, community derived, of financial equilibrium and efficiency -, presents full adherence to the provisions of Constitution Charter, subjecting to tax an assumption meaningful of ability to pay and putting himself in line with article 32 of Constitution, which provides constitutional cover to the protection of human health, even in the broadest sense of well-being physical and emotional (Uricchio, 2015, p. 287; Parente, 2018, p. 95 ff.).

The compliance with the criteria of reasonableness, distributive equity (Giovannini, 2015, p. 675 ff.) and social acceptance might facilitate the circulation of fat taxes, ensuring a lasting application, rather than a precarious and contingent life (Uricchio, 2015, p. 288).

Verified the constitutionality of these forms of levy, it is necessary decline the different configurations that fat taxes can take, being in the abstract two different solutions: the growth and strengthening of existing taxes or the establishment of new taxes levied on food consumption unworthy.

The first solution takes the form of an increase in indirect taxes payable in connection with the consumption of junk foods, accompanied by lightening of taxes affecting the consumption of foods healthy: think of the increase in the rate of VAT (for this solution, adopted in the United Kingdom, comp. 
Marshall, 2000, p. 301 ff.), applicable to the sale of fatty foods and fizzy drinks, associated with the reduction of the rate (this is the solution adopted in Italy with reference to fruits and fresh vegetables already washed, cut and ready to be consumed, including mixed salads, whose sale suffers reduced VAT at the rate of 4\%; on the point, comp. Risoluzione Agenzia delle Entrate, 8 April 2013, n. 23/E; Angeli, 8 April 2013) garrison on the supply of fruit and vegetables (Uricchio, 2015, p. 292).

One variant could be facilitating instruments (on the matter, comp. d'Amati, 2015, p. $25 \mathrm{ff}$.), namely the provision of tax credits or tax deductions to advantage of those practicing an healthy lifestyle: an example of this type is offered by article 15, paragraph 1, lett. i-quinquies of d.P.R. 22 December 1986, n. 917 (T.U.I.R.), which provides for a tax deduction, not exceeding a certain amount, for expenses incurred to attend gyms and other sports facilities (Uricchio, 2015, p. 295, nt. 62).

The second solution is, instead, the establishment of a new tribute (Jacobson - Brownell, 2000, p. 854 ff.; Leicester - Windmeijer, 2004; Salois - Tiffin, 2010), with assumption the consumption or the production of a food harmful to human health, based on the amount of potentially harmful substances in it contains (such as, saturated fats) and calorific value (Uricchio, 2015, p. 292).

\section{THE EXPERIENCES OF FOREIGN LEGAL SYSTEMS AND THE ATTEMPT OF THE ITALIAN LEGISLATOR OF SUBJECT TO TAX THE JUNK FOOD}

Many jurisdictions have embraced the latter solution: one of first experiences took place in Denmark in the 1920s, with the liability to taxation of certain foods containing high amounts of sugars (Uricchio, 2015, p. 295-296).

One diversification of this model was revived recently, through the anticipation of a withdrawal (the fat tax) (Alemanno - Carreño, 2013, p. $223 \mathrm{ff}$.) with as a precondition the consumption of foods (butter, margarine, oils, red meat) containing a percentage of saturated fat more than a certain amount, which the revenue is intended to promote policies to prevent and treat diseases resulting from to eating disorders (Uricchio, 2015, p. 295-296; Magli, 2014, p. 1319, nt. 10; Bivona, 21 ottobre 2011). 
These fiscal measures were accompanied by the tightening of charges applicable at consumer load of certain foodstuffs (chocolate, ice cream, sodas, alcohol) and by attempting to establish a tax on sugars, whose predisposition has been shelved because of difficulties applications, generated by the high number of industrial sweeteners used in the production, which would have made difficult the exact identification of the tax base (Trovato, 2013, p. 12).

Despite the expectations, the adoption of such taxes is not produced the desired effect: on the one hand, the body mass index of population is remained almost unchanged; on the other hand, the increase of sale price, due to the weight of the tax measure, created the crisis of important production chains based on products taxed (such as that of the famous Danish cookies), as well as the opportunity to buy similar food across the border to prices much lower (Uricchio, 2015, p. 296). In this way, the liability to taxation of fatty foods, rather than changing the eating habits of the population, has fuelled the trade borders, for the benefit of the owners of the neighbouring countries, and damaged the local economic activities (Uricchio, 2015, p. 296).

Therefore, the substantial administrative costs to locate the exact incidence of levy, unset on a specific food category but on a ubiquitous component, such as fats (Trovato, 2013, p. 12), the limited contribution in the fight against obesity and gimmicks used to circumvent the levy soon led to the repeal of the legal standards supporting these tax measures (Uricchio, 2015, p. 296).

Worthy of note is the experience of some Scandinavian countries, characterized by a careful legislation to spread healthy lifestyles: the Norway, for almost four decades, followed recently by Finland, introduced a fat tax on sugary drinks and confectionery products; in Sweden, by contrast, adoption of levies on food and on insane drinks is still the subject of lively discussion, both in the academic and government field (Uricchio, 2015, p. 296-297; Trovato, 2013, p. 13).

At the phenomenon of fat taxes are not strangers even the legal systems of Eastern Europe: Hungary, by some years, adopted the chips tax (so called "chipsadó") (Di Muro, 13 luglio 2011), tax that hits, in proportion, the consumption of foods packaged (chips, sugary sodas, chocolate, energy drinks, sweets, salty snacks, sauces) with salt, sugar, carbohydrates or caffeine exceeding certain percentages; in the same order, additional taxes levied on 
manufacturers and importers of sugar-sweetened beverages with content of fruit less than 25\%, candy prepackaged, flavoring food, alcoholic drinks, nonalcoholic aperitifs sweetened and salted snack (Uricchio, 2015, p. 296; Magli, 2014, p. 1319, nt. 10; Trovato, 2013, p. 13).

A attempt to introduce similar tax measures was proposed in Romania: the idea was dropped to avoid exacerbate the living conditions of the weakest members of the population, already tested by the climate of global recession caused by the recent economic crisis (Trovato, 2013, p. 14).

The French legal system (Hespel - Berthod-Wurmser, La documentation française/Inspection générale des Finances/Inspection générale des Affaires sociales La documentation française/Inspection générale des Finances/ Inspection générale des Affaires sociales La documentation française/ Inspection générale des Finances/Inspection générale des Affaires sociales2008), in addition to increasing the levy on luxuries entity (cigarettes, spirits and rum), after trying unsuccessfully to establish the "tax on the nutella" (Moussanet, 15 November 2012, p. 47; Fazzino, 15 November 2012, p. 47), for hitting the ingredient on which it is based, namely, palm oil, notoriously fat substance, introduced the "Coca Cola tax", also called "Taxe soda", applied to consumption of carbonated soft drinks at the time of sale to the detail, at the rate of two cents per canned drink (Uricchio, 2015, p. 296297). The proceeds from the levy is bound to benefit in the primary sector (reduction of yhe labour costs of harvesting in agriculture and livelihood of fruit and vegetables productions) (Uricchio, 2015, p. 296-297; Magli, 2014, p. 1319, nt. 10; Trovato, 2013, p. 13-14).

In Israel, but especially in the United Kingdom, are thinking of setting up a tax paid by people wishing to start a business meant sell fatty products, like fish and chips and kebabs, to extend to the entire national territory an existing locally tax, that is, in the English town of Oldham, characterized by very high rates of obesity in childhood; in Ireland, is discussed a similar tax measure imposed on sodas (Uricchio, 2015, p. 297; Trovato, 2013, p. 14).

Even overseas has spread the use of fat taxes: even without a harmonised tax at the federal level, in some legal systems of the United States of America (Arkansas, Tennessee, Virginia and West Virginia), pioneers in the field, have been in place selective tax measures applied to sale of sugary drinks, in 
an amount equal to $3-5 \%$ of the sale price, in order to put a stop to obesity (Uricchio, 2015, p. 297).

Not have been different choices: in Maine and Washington State were repealed the existing fat taxes, unlike other States of North America (Arizona, California, Connecticut, Hawaii, Illinois, Mississippi, Montana, New Mexico, Oregon, Rhode Island, Texas, Utah, Vermont, Massachusetts and New York), where the discussion was lively, that have prepared draft laws on how taxing the junk food, for subjecting to taxation the "gluttony" of taxpayers (Trovato, 2013, p. 11-12).

In Italy, whose legal system did not remain foreign to the new wave of health policy, an unsuccessful attempt to introduce a tax on consumption not deserving - with tax revenue destined to part in the funding of essential assistance levels (LEA) and partly to the term care programme - was performed in 2012 with the draft of the Decree Balduzzi (the proposed establishment of a fat tax was removed in final version od decree-law 13 September 2012, n. 158, converted with modifications by law 8 November 2012, n. 263; on this topic, comp. Sassi, 2013, p. 163 ff.), which has provided an extraordinary contribution, based on the amount of product placed on the market, borne by producers of spirits and drinks drinks with added sugars and sweeteners (on the tax measure, which had sparked criticism by associations of category, comp. Scarci, 28 August 2012, p. 8).

In the legislator's intentions, the consumption of carbonated drinks would have to pay a levy equal to two cents of euro per canned drink, unlike the consumption of unhealthy foods, exempt from withdrawal forms, provided that the producers high its qualitative standards (Uricchio, 2015, p. 297-298; Magli, 2014, p. 1319; Trovato, 2013, p. 14).

Such indirect tax, concerning foods rich in calories, was supposed to be a deterrent for the consumer, allowing to internalize the social costs related to that particular consumer option (Magli, 2014, p. 1319; Ferrari - Izzo, 2012, p. 294). However, the reactions submitted by the producers and consumers have induced, at first, to postpone the adoption of the measure and, subsequently, totally deleted (Trovato, 2013, p. 14).

Emerges, however, the general tendency to strengthen the public protection of the consumer, by addressing towards models of food life based on prevention (Magli, 2014, p. 1320). 
In the Italian legal system, because health care falls within the legislative competitors competence (article 117, paragraph 3, Constitution), the fat taxes, in accordance with the principles governing fiscal federalism (law 5 May 2009, n. 42) (on the matter, comp. Gallo, 2012, p. 23 ff.; Uricchio, 2012), may be established by individual regions, within the limits of national and Community legislation (on the subject, comp. Torchia, 2001, p. 1203; Ficari, 2002, p. 1229 ff.; Carinci, 2004, p. 1201 ff.; Greggi, 2008, p. $1448 \mathrm{ff}$.), in order to protect health, safeguarding the culinary traditions rooted in the individual territories of the peninsula (Uricchio, 2015, p. 299-300).

\section{THE PROPOSAL TO HARMONISE THE FAT TAXES IN THE EUROPEAN UNION}

In truth, given that a serious policy to fight against obesity cannot be only local or national scope, it would be advisable to harmonize the taxation about fatty foods, at least at Community level, like what happened with the discipline of excise duties, in order to limit the taxable object to certain substances and quantity harmful to human health, while preserving the principle of nondiscrimination and fundamental freedoms of European Union legal system and leaving to the individual Member States the power to define in detail the assumption taxed and the application methods of the charge, to safeguard, next to the traditions and cultural identity of the place, the demographic and health characteristics of the population (Uricchio, 2015, p. 298-299; Alemanno - Carreño, 2013, p. 232 ff.).

Indeed, in the abstract, the taxation limited to certain types of harmful products could appear discriminatory, resulting in violation of article 110 of the Treaty on the functioning of the European Union (TFEU), where limited to substances - potentially harmful to human health - from other States Members, becoming a sort of customs duty; in practice, however, this event would be remote, given the structure of fat taxes and limited impact within international trade (Uricchio, 2015, p. 299).

Even the World Trade Organization (WTO), with the General Agreement on tariffs and trade, known as GATT, has banned to the acceding States the application of internal taxes on imported products greater than those 
to which are subject to domestic products, in order to protect the domestic production (Alemanno - Carreño, 2013, p. 234).

In the current system of sources, there are obstacles to the adoption of a tax about fatty foods at Community level: the exact identification of the base of the tax raises critical issues, since both the health policies that the tax policies are a prerogative of domestic legislation, as reaffirmed by Treaty on the functioning of the European Union (TFEU), which, in articles 6, lett. a), and 168, paragraph 2, limits the powers of the Union to the coordination, support and integration of measures taken by the Member States and in article 9 raises the protection of public health to basic demand of the Union in the implementation of any measure or activity (Alemanno - Carreño, 2013, p. 232; on the matter, comp. Craig, 2010, p. 325; Piris, 2010, p. 320-321).

Nevertheless, in several occasions, the European Union has proven to be equipped with proper tools to develop an effective policy to prevent obesity: is by example the EU regulation of 25 October 2011, n. 1169 (on the matter, comp. Di Lauro, 2012, p. 1 ff.) (concerning statements on nutrition and health), aimed to assist consumers in selecting healthy products, which requires food businesses to substantiate the statements contained in the labels (Alemanno - Carreño, 2013, p. 233).

Therefore, even the establishment of a European fat tax could rise to important prevention tool: will need to identify, for the entire Union territory, a rate that takes into account the differences between the various Member States (Berghöfer - Pischon - Reinhold - Apovian - Sharma - Willich, 2008, p. 200), in spread of obesity (Alemanno - Carreño, 2013, p. 233-234).

\section{THE PROBLEMS ARISING THE USE OF FAT TAXES AND REGRESSIVE SCOPE OF SUCH FORMS OF LEVY. THE USE OF TAXATION TO FUND NUTRITION EDUCATION INTERVENTIONS}

In terms of effectiveness, the use of taxation to protect human health, at least in domestic legislation, did not have the desired effect: the uptake of fat taxes, within individual jurisdictions, has raised many complaints (on the subject, comp. Chouinard - Davis - Lafrance - Perloff, 2005; Chouinard - Davis - Lafrance - Perloff, 2007; Mytton - Gray - Rayner - Rutter, 2007, 
p. 689 ff.; Griffith - Nesheim, 2008; Goldman - Lakdawalla - Zheng, 2009; Yaniv - Rosin - Tobol, 2009, p. 823 ff.; Allais - Bertail - Nichéle, 2010, p. $228 \mathrm{ff}$.), giving a withdrawal form ineffective, unfair and damaging to the competition.

From the empirical analysis showed that, especially in the short term, the use of such taxes did not change consumer preferences in terms of reduction in the consumption of junk food; indeed, created distortions in market equilibrium. Hence, the regressive trend range of these forms of levy (Uricchio, 2015, p. 293-294).

In addition, the fat taxes, often, took the physiognomy of a mere instrument of revenue or expedient in defense of vested interests within individual jurisdictions (Alemanno - Carreño, 2013, p. 236), especially in cases where the protection of human health is only served to provide ethical justification to levy, to make it acceptable to the general of the contributors: right ethical arguments have served to give legitimacy to an instrument that is more like a form of remuneration rather than a means of deterrence (Trovato, 2013, p. 7).

Finally, in the long run, tax measures against obesity may prejudice the "rights of fat", engraving on heterogeneous entities, such as, identity, personal characteristics, moral responsibility, governmental response and legal protection (Alemanno - Carreño, 2013, p. 236; in addition, on the matter, comp. Campos, 2004; Olivier, 2006; Kirkland, 2008, p. 3).

The first appearance, source of harm to economic system, relates to the situation where the fat taxes are structured in so as not to hit all types of junk food: in this case, in fact, the consumer, following the introduction of a tax on certain drinks sweetened, may decide to direct the consumption to price drinks lower, potentially much more harmful to human health (Uricchio, 2015, p. 294).

The regressive flow of fat taxes is not less irrelevant, given that the economic burden of the tax would be borne from the poorer classes, who consume more food than poor quality present on the market at a lower price (Uricchio, 2015, p. 294; in addition, on the matter, comp. Caraher - Cowburn, 2005, p. 1242 ff.; Lagravinese, 20 January 2012; Caccioni, 9 October 2012; Salerno, 11 December 2012; Shughart II, 2013, p. 35 ff.). 
For make less regressive this tool could use a tribute of purpose (on the matter, comp. Uricchio, 2015, p. $151 \mathrm{ff}$.), binding a share of the proceeds to the payment of subsidies in favour of consumers, to orient the choice of buying healthy food (Uricchio, 2015, p. 294); would be, instead, to avoid forms of aid in favour of producers, to ward the violation of the ban of the State aid (articles 107-108 TFEU) (about tax profiles of the ban of the State aid, comp. Fichera, 1998, p. 84 ff.; Salvini, 2007; Ingrosso - Tesauro, 2009; Aulenta, 2015, p. 87 ff.; for the application of the prohibition on food taxation, comp. Gonzàlez Vaqué, 2017, p. 34 ff.; Mayoral, 2017, p. 3 ff.).

An alternative remedy, which, however, while using the tribute of purpose, not totally resolves the problem, would be to set aside a share of tax income to the provision of welfare policies, through the financing of health services for the population groups most at risk (Uricchio, 2015, p. 294; Dirindin - Brenna - Di Novi, 7 February 2012): doing so, however, health protection would only postponed.

Perhaps, the best solution would be to use the revenue from fat taxes to finance nutrition education policies to promote healthy eating patterns, being shown that educational interventions (Sassi, 2013, p. $143 \mathrm{ff}$.), especially in the long run, appear much more effective than any other policy and result in a substantial reduction of the population overweight (Uricchio, 2015, p. 294-295; Caraher - Cowburn, 2005, p. 1242 ff.; Kuchler - Tegene - Harris, 2005, p. 4 ff.; Tiffin - Salois, 2013, p. 143 ff.).

In fact, the fiscal tightening of not meritorious consumption give to the State a stock to be allocated to finance advertising and informative campaigns, discouraging the consumption of harmful products and realizing economies in health expenditure (Uricchio, 2015, p. 303; Magli, 2014, p. 1319).

\section{References}

Adams, C. (2007). For Good and Evil. L'influsso della tassazione sulla storia dell'umanità. Macerata: Liberilibri. ISBN 9788895481036.

Aizega Zubillaga, J.M. (2001). La utilización extrafiscal de los tributos y los principios de justicia tributaria. Bilbao: Universidad del País Vasco, Servicio Editorial. ISBN 847585656X. 
Alemanno, A. - Carreño, I. (2013). Imposte sui grassi nell'UE: tra austerità fiscale e lotta all'obesità. in: M. Trovato (edited by), Obesità e tasse. Perché serve l'educazione, non il fisco. Torino: IBL Libri, ss. 235. ISBN 8864400850.

Allais, O. - Bertail, P. - Nichéle, V. (2010). The Effects of a Fat Tax on French Household's Purchases: a Nutritional Approach. American Journal of Agricultural Economics, 1, p. 228. ISSN 1467-8276.

Allena, M. (2005). Gli effetti giuridici della traslazione delle imposte. Milano: Giuffrè. ISBN 9788814113383.

Angeli, S. (8 April 2013). Insalate miste pronte da mangiare. A dieta anche l'Iva: aliquota al 4\%. www.fiscooggi.it. (access 28.07.2019).

Antonini, L. (1996). Dovere tributario, interesse fiscale e diritti costituzionale. Milano: Giuffrè. ISBN 9788814057670.

Aulenta, M. (2015). Gli aiuti di Stato. in: A.F. Uricchio, M. Aulenta, G. Selicato, La dimensione promozionale del fisco. Bari: Cacucci, p. 87. ISBN 9788866114901.

Balladores Saballos, R. (2013). Le imposte con fini extrafiscali. Profili fiscali e di teoria generale. in: A.F. Uricchio (edited by), Imposizione di scopo e federalismo fiscale. Santarcangelo di Romagna (RN): Maggioli, p. 29. ISBN 9788838775161.

Batistoni Ferrara, F. (1999). Capacità contributiva. in: Enc. dir., Aggiornamento, III. Milano: Giuffrè, p. 345.

Berghöfer, A. - Pischon, T. - Reinhold, T. - Apovian, C.M. - Sharma, A.M. - Willich, S.N. (2008). Obesity prevalence from a European perspective: a sistematic review. BMC Public Health, 8, p. 200. ISSN 1471-2458.

Berliri, A. (1974). Corso istituzionale di diritto tributario. Milano: Giuffrè, p. 114. ISBN 8814011753.

Bivona, B. (21 October 2011). Danimarca: una fat tax a misura di linea e portafoglio. FiscoOggi.

Boria, P. (2002). L’interesse fiscale. Torino: Giappichelli. ISBN 9788834822685.

Boria, P. (2004). Le accise. w: A. Fantozzi, Corso di diritto tributario. Torino: Utet, p. 504. ISBN 9788802061917.

Boria, P. (2008). Il sistema tributario. Milanofiori Assago (MI): Utet Giuridica, p. 811. ISBN 9788859802952.

Brownell, K.D. (15 December 1997). Get slim with higher taxes. The New York Times, p. 2. ISSN 0362-4331.

Brownell, K.D. - Battle Horgen, K. (2004). Food fight: the inside story of the food industry, America’s obesity crisis and what we can do about it, New York: McGraw-Hill Education, 2004. ISBN 0071438726. 
Caccioni, D. (9 October 2012). Costa caro il cibo spazzatura. www.lavoce.info (access 17.07.2019).

Campos, P. (2004). The obesity myth. Why America's obsession with weight is hazardous to your health. New York: Gotham Books. ISBN 9781592400669.

Caraher, M. - Cowburn, G. (2005). Taxing food: implications for public health nutrition. Public Health Nutrition, 8, p. 1242. ISSN 1368-9800.

Carano Donvito, G. (1928). L'economia meridionale prima e dopo il Risorgimento. Firenze: Vallecchi, p. 286.

Carinci, A. (2004). Autonomia tributaria delle Regioni e vincoli del Trattato dell'Unione Europea. Rass. trib., p. 1201.

Cavanna, V. (2014). La normativa comunitaria e interna in materia di Ogm: il D.M. n. 187/2013. Amb. svil., p. 464.

Cavanna, V. (2014). Ogm: legittimo il divieto in via cautelare di coltivazione del mais Mon810. Amb. svil., p. 548.

Censi, D. (2017). Il meccanismo europeo di stabilità e il Fiscal Compact. Modena: ADAPT University Press.

Cerrato, M. (1996). Spunti intorno alla struttura ed ai soggetti passivi delle accise. Riv. dir. trib., I, p. 215.

Chouinard, H. - Davis, D. - Lafrance, J. - Perloff, J. (2005). The Effects of a Fat Tax on Dairly Products. CUDARE, Working Paper. no. 1007. ISSN 0898-2937.

Chouinard, H. - Davis, D. - Lafrance, J. - Perloff, J. (2007). Fat Taxes: Big Money for Small Change. Forum for Health Economics and Policy. www.bepress.com/ fhep/10/2/2. (access 27.07.2019)

Cipolla, G.M. (2003). Presupposto, funzione economica e soggetti passivi delle accise nelle cessioni di oli minerali ad intermediari commerciali. Rass. trib., p. 1859.

Cipolla, G.M. (2006). Accise. in: Dizionario di Diritto Pubblico, diretto da S. Cassese, I. Milano: Giuffrè, p. 72. ISBN 8814121583.

Craig, P. (2010). The Treaty of Lisbon. Law, Politics and Treaty Reform. Oxford: Oxford University Press, p. 325. ISBN 9780199664955.

d'Amati, N. (1964). Schema costituzionale dell'attività impositiva. Dir. e prat. trib., I, p. 464.

d'Amati, N. (1973). La progettazione giuridica del reddito. Padova: Cedam, I, p. 106. ISBN 9788854839083. 
d'Amati, N. (1985). Diritto tributario. Teoria e critica. Torino: Utet, p. 82. ISBN 8802039518.

d'Amati, N. (2015). Agevolazioni ed esenzioni tributarie. in: A.F. Uricchio, M. Aulenta, G. Selicato, La dimensione promozionale del fisco. Bari: Cacucci, p. 25. ISBN 9788866114901.

D’Amico, N. (2012). I rapporti fra la nuova legge costituzionale e il Fiscal Compact. Giorn. dir. amm., 10, p. 933.

De Mita, E. (1984). Fisco e Costituzione. Questioni risolte e questioni aperte, 1957-1983. Milano: Giuffrè. ISBN 9788814002755.

De Mita, E. (1987). Capacità contributiva. in: Dig. disc. priv., sez. comm., II. Torino: Utet, p. 454.

Di Benedetto, D. (2011). La disciplina degli organismi geneticamente modificati tra precauzione e responsabilità. Napoli: ESI. ISBN 9788849521863.

Di Lauro, A. (2012). Nuove regole per le informazioni sui prodotti alimentari e nuovi analfabetismi. La costruzione di una "responsabilità del consumatore". Riv. dir. alimentare, 2, p. 1.

Di Muro, G. (13 July 2011). Ungheria: in arrivo la chips tax. Stop a malattie e obesità. www.fiscooggi.it. (access 27.07.2019).

Di Pietro, A. (2012). Federalismo fiscale e nuova governance europea. in: Aa.Vv., Governo della finanza pubblica e federalismo fiscale. Bari: Cacucci, p. 130. ISBN 9788866111610 .

Dirindin, N. - Brenna, E. - Di Novi, C. (7 February 2012). Tassare il cibo spazzatura?. www.lavoce.info. (access 27.07.2019).

Donatelli, S. (2019). Dovere fiscale e tributi extrafiscali. Rass. trib., 2, p. 312.

Drenkard, S. (2013). Strafare nella lotta all’obesità. in: M. Trovato (edited by), Obesità e tasse. Perché serve l'educazione, non il fisco. Torino: IBL Libri, p. 195. ISBN 8864400850 .

Dworkin, G. (2002). Paternalism. w: E.N. Zalta (edited by), The Stanford Encyclopedia of Philosophy. http://plato.stanford.edu/entries/paternalism/__(access 27.07.2019).

Falsitta, G. (2014). Corso istituzionale di diritto tributario, V ed. Padova: Cedam, p. 631. ISBN 8813340311.

Fazzino, E. (15 November 2012). Tassa sulla Nutella in Francia, per ora nulla di fatto. Il Sole 24 Ore, p. 47. 
Fedele, A. (1999). Dovere tributario e garanzie dell'iniziativa economica e della proprietà nella Costituzione italiana. Riv. dir. trib., I, p. 971.

Ferrari, M. - Izzo, U. (2012). Diritto alimentare comparato. Regole del cibo e ruolo della tecnologia. Bologna: Il Mulino. ISBN 9788815239563.

Ficari, V. (2002). «Scintille» di autonomia tributaria regionale e limiti interni e comunitari. Rass. trib., p. 1229.

Fichera, F. (1973). Imposizione ed extrafiscalità nel sistema costituzionale. Napoli: ESI.

Fichera, F. (1973). La giurisprudenza della Corte costituzionale sul tema dei rapporti tra imposizione ed extrafiscalità. Dir. prat. trib., II, p. 774.

Fichera, F. (1997). Larmonizzazione delle accise. Riv. dir. fin. sc. fin., I, p. 216.

Fichera, F. (1998). Gli aiuti fiscali nell'ordinamento comunitario. Riv. dir. fin. sc. fin., 1, p. 84.

Gaffuri, G. (1969). Lattitudine alla contribuzione. Milano: Giuffrè.

Gaffuri, G. (2008). Garanzie di giustizia e diritto tributario: la capacità contributiva. Iustitia, 4, p. 429. ISSN 1640-8365.

Gallo, F. (2012). L'uguaglianza tributaria. Napoli: Editoriale Scientifica. ISBN 9788863424669.

Gallo, F. (2012). I principi del federalismo fiscale. Dir. prat. trib., I, p. 23.

Giardina, E. (1961). Le basi teoriche del principio di capacità contributiva. Milano: Giuffrè.

Giovannini, A. (2013). Capacità contributiva in: Treccani. Diritto on line. http:// www.treccani.it/enciclopedia/capacita-contributiva_(Diritto-on-line)/. (access 27.07.2019).

Giovannini, A. (2015). Equità impositiva e progressività. Dir. prat. trib., 5, p. 675.

Giovannini, A. (2016). Ripensare la capacità contributiva. Dir. prat. trib., 1, p. 15.

Glaeser, E. (2013). Paternalismo e psicologia. in: M. Trovato (edited by), Obesità e tasse. Perché serve l'educazione, non il fisco. Torino: IBL Libri, p. 107. ISBN 8864400850 .

Goldman, D. - Lakdawalla, D. - Zheng, Y. (2009). Food prices and the dynamics of body weight. w: The National Bureau of Economic Research, Working Paper. no. 15096. ISSN 0898-2937.

Gonzàlez Vaqué, L. (2017). La sentenza "Superfoz" relativa alla tassa sul controllo dei prodotti alimentari: un precedente pericoloso?. Riv. dir. alimentare, 3, p. 34. 
Greggi, M. (2008). Tributi regionali e vincoli comunitari: i limiti europei alla potestà impositiva regionale (quando il controllo di compatibilità comunitaria passa anche attraverso la Corte Costituzionale). Rass. trib., p. 1448.

Griffith, R. - Nesheim, L. (2008). Empirical Estimates of the Impact of a Fat Tax. www.idei.fr. (access 27.07.2019).

Griziotti, B. (1953). Il principio di capacità contributiva e le sue applicazioni. in: Saggi sul rinnovamento degli studi di scienza delle finanze e diritto finanziario. Milano: Giuffrè, p. 351.

Hespel, V. - Berthod-Wurmser, M. (2008). Rapport su la pertinence et la faisabilité d'une taxation nutritionnelle. Parigi: La documentation française. Inspection générale des Finances. Inspection générale des Affaires socialesLa documentation française/Inspection générale des Finances/Inspection générale des Affaires sociales La documentation française/Inspection générale des Finances/Inspection générale des Affaires sociales La documentation française/Inspection générale des Finances/Inspection générale des Affaires sociales.

Holcombe, R. (2013). Teoria politica della tassazione selettiva. in: M. Trovato (edited by), Obesità e tasse. Perché serve l'educazione, non il fisco. Torino: IBL Libri, p. 61. ISBN 8864400850.

Ingrosso, M. - Tesauro, G. (edited by) (2009). Agevolazioni fiscali e aiuti di Stato. Napoli: Jovene. ISBN 9788824318976.

Jacobson, M. - Brownell, K.D. (2000). Small taxes on soft drinks and snack foods to promote health. American Journal of Public Health, 90, p. 854. ISSN 0090-0036.

Kirkland, A. (2008). Fat rights. Dilemmas of difference and personhood. New York: New York University Press. ISBN 0814748139.

Kuchler, F. - Tegene, A. - Harris, J.M. (2005). Taxing Snack Food: Manipulating Diet Quality Or Financing Information Programs?. Review of Agricoltural Economics, 1, p. 4. ISSN 1467-9353.

Labate, G. (2012). Sovrappeso, obesità, disordini alimentari: una sfida da cogliere per guadagnare salute nel $21^{\circ}$ secolo. Organizzazione sanitaria, 3, p. 20. ISSN 19709374.

Lagravinese, R. (20 January 2012). Una "fat tax" per ridurre l'obesità in Italia?. www. nelmerito.com. (access 27.07.2019)

La Rosa, S. (1981). Costituzione, Corte Costituzionale e diritto tributario. Dir. e prat. trib., I, p. 233.

Leicester, A. - Windmeijer, F. (2004). The "fat tax": Economic Incentives to Reduce Obesity, Briefing Note no. 49. London: The Institute for Fiscal Study. 
Maffezzoni, F. (1970). Il principio di capacità contributiva nel diritto tributario italiano. Torino: Utet.

Magli, C. (2014). Diritto alla salute e stili di vita: la condotta del singolo può modificare la modulazione del trattamento sanitario?. Contratto e impresa, 6, p. 1316. ISSN 1123-5055.

Manzoni, I. (1967). Il principio di capacità contributiva nell’ordinamento costituzionale italiano. Torino: Giappichelli.

Marini, L. (2004). Principio di precauzione, sicurezza alimentare e organismi geneticamente modificati nel diritto comunitario. Dir. un. eur., p. 7.

Marini, L. (2007). Ogm, precauzione e coesistenza: verso un approccio bio(politicamente) corretto?. Riv. giur. amb., p. 1.

Marongiu, G. (1985). Il principio di capacità contributiva nella giurisprudenza della Corte Costituzionale. Dir. e prat. trib., I, p. 6.

Marshall, T. (2000). Exploring a fiscal food policy: the case of diet and ischaemic heart disease. British Medical Journal, p. 301. ISSN 0959-8138.

Mayoral, A. (2017). Cuando lo importante es recaudar. Incoherencia y desacierto della jurisprudencia del TJUE en materia de tasas sobre los controles alimentarios. Documento de trabajo CEEUDECO, 2, p. 3.

Micheli, G.A. (1967). Capacità contributiva reale e presunta. Giur. cost., I, p. 1530.

Moschetti, F. (1973). Il principio della capacità contributiva. Padova: Cedam. ISBN 9788813139124.

Moschetti, F. (1988). Capacità contributiva.in: Enc. giur. Treccani, V. Roma: Istituto della Enciclopedia Italiana, p. 1.

Moschetti, F. (2007). Il principio di capacità contributiva espressione di un sistema di valori che informa il rapporto tra singolo e comunità. in: L. Perrone - C. Berliri, Diritto tributario e Corte Costituzionale. Napoli: ESI, p. 44. ISBN 978-8849513516.

Moussanet, M. (15 November 2012). La Francia vota la tassa-Nutella. Il Sole 24 Ore, p. 47. Mytton, O. - Gray, A. - Rayner, M. - Rutter, H. (2007). Could targeted food taxes improve health?. Journal of Epidemiology and Community Health, p. 689. ISSN 1470-2738.

Napolitano, G. (2012). Il meccanismo europeo di stabilità e la nuova frontiera costituzionale dell'Unione. Riv. dir. amm., 5, p. 461.

Nucciarelli, A. (2012). Paternalismo. in: Dizionario di Economia e Finanza. http:// www.treccani.it/enciclopedia/paternalismo_\%28Dizionario-di-Economia-e-Finanza\%29/ (access 27.07.2019). 
Olivier, E. (2006). Fat politics. The real story behind America's obesity epidemic. New York: Oxford University Press. ISBN 9780739468609.

Oms (2004). Global Strategy on Diet, Physical Activity and Health. Ginevra: World Health Organization.

Oms (2008). Action Plan for the Global Strategy for the Prevention and Control of Non-communicable Diseases 2008-2013. Ginevra: World Health Organization.

Pace, A. (1994). Il mondo delle accise: le imposte di fabbricazione. I monopoli fiscali. Le imposte doganali. In: A. Amatucci (edited by), Trattato di diritto tributario, IV. Padova: Cedam, p. 267. ISBN 9788813230692.

Parente, F. (2018). Dalla persona biogiuridica alla persona neuronale e cybernetica. La tutela post-moderna del corpo e della mente. Napoli: ESI, p. 95. ISBN 9788362753857.

Parente, S.A. (2013). Lo ius impositionis tra potere autoritativo, solidarietà sociale e libertà personale. w: Annali del Dipartimento Jonico in "Sistemi Giuridici ed Economici del Mediterraneo: società, ambiente, culture" - Università degli Studi di Bari "Aldo Moro" 2013 - Anno I. www.annalidipartimentojonico.org, p. 513. (access 27.07.2019).

Perez, R. (2012). Dal bilancio in pareggio all'equilibrio tra entrate e spese. Giorn. dir. amm., 10, p. 929.

Perrone, L. (1997). Appunti sulle garanzie costituzionali in materia tributaria. Riv. dir. trib., I, p. 577.

Pigou, A.C. (1948). Economia del benessere. Torino: Utet.

Piris, J.C. (2010). The Treaty of Lisbon. A Legal and Political Analysis. Cambridge: Cambridge University Press. ISBN 9780521142342.

Quaglino, L. (2013). Tassare il "cibo spazzatura"? Una rassegna della letteratura: in: M. Trovato (edited by), Obesità e tasse. Perché serve l'educazione, non il fisco. Torino: IBL Libri, p. 239. ISBN 8864400850.

Risoluzione Agenzia delle Entrate, 8 April 2013, n. 23/E. https://www.agenziaentrate. gov.it/wps/file/nsilib/nsi/normativa+e+prassi/risoluzioni/archivio+risoluzioni/risoluzioni+2013/aprile+2013+risoluzioni/risoluzione $+23+08042013+$ prodotti+ortofrutticoli+iv+gamma/RIS+23e+dell\%278+04+13.pdf (access 27.07.2019).

Russo, P. (2007). Manuale di diritto tributario. Parte generale. Milano: Giuffrè, p. 48. ISBN 9788814136870.

Salerno, N.C. (11 December 2012). Food tax alla prova. www.nelmerito.com. (access 27.07.2019). 
Salois, M.J. - Tiffin, R. (2010). Fat Taxes and Thin Subsidies: Distributional Impacts and Welfare Effects. https://pdfs.semanticscholar.org/042a/1e0895cfe9c79b56b731997368ab55b0577e.pdf. (access 27.07.2019).

Salvini, L. (edited by) (2007). Aiuti di Stato in materia fiscale. Padova: Cedam.

Sassi, F. (2013). Informazione, incentivi e scelta: un approccio realistico alla prevenzione dell'obesità. in: M. Trovato (edited by), Obesità e tasse. Perché serve l'educazione, non il fisco. Torino: IBL Libri, p. 163. ISBN 8864400850.

Scarci, E. (28 August 2012). I produttori: “La tassa non dà salute”. Il Sole 24 Ore, p. 8. ISSN 0391-786X.

Schiavolin, R. (2000). Accise. in: Enc. dir., Aggiornamento, IV. Milano: Giuffrè, p. 22.

Shughart II, W. (2013). Teoria economica dello Stato-mamma. in: M. Trovato (edited by), Obesità e tasse. Perché serve l'educazione, non il fisco. Torino: IBL Libri, p. 35. ISBN 8864400850.

Tafaro, L. (2014). Applicazioni biotecnologiche nel mercato agroalimentare. in: M. Pennasilico (edited by), Manuale di diritto civile dell'ambiente. Napoli: ESI, p. 253. ISBN 9788849527865.

Tesauro, F. (2008). Istituzioni di diritto tributario, 2, Parte speciale. Milanofiori Assago (MI): Utet Giuridica, p. 344.

Thow, A.M. - Jan, S. - Leeder, S. - Swinburn, B. (2010). The impact of fiscal policy interventions for diets, obesity and chronic disease: a systematic review. Bulletin of the World Health Organization, p. 609. ISSN 1564-0604.

Tiffin, R. - Salois, M. (2013). Disuguaglianze nell'alimentazione e nella nutrizione letteratura. in: M. Trovato (edited by), Obesità e tasse. Perché serve l’educazione, non il fisco. Torino: IBL Libri, p. 143. ISBN 8864400850.

Torchia, L. (2001). I vincoli derivanti dallordinamento tributario nel nuovo Titolo V della Costituzione. Le regioni, p. 1203.

Trovato, M. (2013). Introduzione. in: M. Trovato (edited by), Obesità e tasse. Perché serve l'educazione, non il fisco. Torino: IBL Libri, p. 7. ISBN 8864400850.

Trovato, M. (edited by) (2013). Obesità e tasse. Perché serve l'educazione, non il fisco. Torino: IBL Libri.

Tullock, G. (2013). Le accise in una società rent-seeking. in: M. Trovato (edited by), Obesità e tasse. Perché serve l'educazione, non il fisco. Torino: IBL Libri, p. 97. ISBN 8864400850.

Uricchio, A.F. (2012). Il federalismo della crisi o la crisi del federalismo?. Bari: Cacucci. ISBN 8838781070. 
Uricchio, A. (2013). La tassazione sugli alimenti tra capacità contributiva e fini extrafiscali. Rass. trib., 6, p. 1268.

Uricchio, A. (2015). La tassazione sugli alimenti tra capacità contributiva e fini extrafiscali. in: A.F. Uricchio - M. Aulenta - G. Selicato, La dimensione promozionale del fisco. Bari: Cacucci, p. 290. ISBN 9788866114901.

Uricchio, A. (2015). Limposizione di scopo. in: A.F. Uricchio - M. Aulenta - G. Selicato, La dimensione promozionale del fisco. Bari: Cacucci, p. 151. ISBN 9788866114901.

Uricchio, A.F. (2017). Percorsi di diritto tributario. Bari: Cacucci. ISBN 9788866115717.

Uricchio, A.F. - Aulenta, M. - Selicato, G. (2015). La dimensione promozionale del fisco. Bari: Cacucci. ISBN 9788866114901.

Verrigni, C. (2003). Le accise. in: Aa.Vv., Lo stato della fiscalità nell'Unione Europea. Lesperienza e l'efficacia dell'armonizzazione, I. Roma: Ministero dell'Economia e delle Finanze. Dipartimento per le politiche fiscali. Ufficio comunicazione istituzionale, p. 487.

Verrigni, C. (2007). Le accise nel mercato unico europeo. Riv. dir. fin. sc. fin., I, p. 251.

Williams, R. - Christ, K. (2013). Tassare i vizi: le accise sono efficienti?. in: M. Trovato (edited by), Obesità e tasse. Perché serve l'educazione, non il fisco. Torino: IBL Libri, p. 187. ISBN 8864400850.

Yaniv, G. - Rosin, O. - Tobol, Y. (2009). Junk-food, home cooking, physical activity and obesity. The effect of the fat tax and the thin subsidy. Journal of Public Economics, ss. 823. ISSN 0047-2727. 